\title{
APIE KAI KURIAS ŠIUOLAIKINES AIKŠČIŲ FORMAVIMO TENDENCIJAS ${ }^{1}$ LIETUVOJE $^{2}$
}

\author{
Tomas Grunskis \\ Architektūros pagrindų ir teorijos katedra, Vilniaus Gedimino technikos universitetas, \\ Pylimo g. 26/Traku g. 1, LT-01132 Vilnius, Lietuva, \\ El.paštas grunskis@gmail.com \\ Itteikta 20090618
}

Santrauka. Straipsnyje aptariama šiuolaikinè miesto pagrindinių aikščių formavimo situacija Lietuvoje, išskiriant ir apibūdinant kelis svarbiausius bruožus. Čia analizuojama kintanti miesto viešųjų erdvių samprata ir jų pavyzdžiai, kintanti miesto viešųjų erdvių tipologija bei kintantys visuomenès reikalavimai aikšių ir paties miesto formavimui. Tekste išskiriamos ir aptariamos kai kurios aiškiau matomos aikščių formavimo tendencijos bei idejjos.

Reikšminiai žodžiai: miesto morfologija, viešoji erdve, aikštė, semiologinis tekstas, tendencijos.

\section{Ivadas}

Miesto raidos istorijoje dvidešimt metų nèra didelis laiko tarpas, ypač jeigu tos raidos sociokultūrinio konteksto sąlygas galima apibūdinti kaip palankias arba normalias, o pats miestas yra pletojamas tolygiai ir planingai. Pagreitintos urbanizacijos sąlygomis, kai miestas visais požiūriais yra plètojamas itin sparčiai, o konteksto sąlygos tą plètrą skatina, padètis atrodo gerokai blogiau. Lietuva šiandien, XXI a. pr., pergyvena jau atslūgstantị antrąji tokios akseleruojančios urbanizacijos etapą ${ }^{2}$. Pirmojo tokio panašaus etapo metu - pirmosios Lietuvos Respublikos metais nuo 1918 iki 1940 metų - buvo sukurta ir sparčiai išvystyta nacionalinès sostinès idejja, kurią igyvendinus tuo metu Kaune per bemaž dvidešimt metų buvo sufor-

\footnotetext{
${ }^{1}$ Tendencija čia suprantama taip, kaip terminą aiškina tarptautinių žodžių žodynas - tendencij|a: 1) vyksmo, veiksmo, raidos, pažiūros, nuomonès, skonio ir kt. kryptis, polinkis, „Tarptautiniu žodžių žodynas“ (2004).

${ }^{2}$ Apie urbanizacijos etapus Lietuvoje yra rašę A. Miškinis (1991) ir K. Šešelgis (1996). Visi autoriai sutinka, kad reikšminga buvo XIX a. industrinè revoliucija ir miestu plètra, Lietuvai esant Rusijos imperijos dalimi. Vilniaus miesto urbanizacijos etapai taip pat aptarti šio teksto autoriaus leidinyje „Pastabos apie Vilniaus miesto raidą. Vilnius 1900-2005. Naujosios architektūros gidas".
}

muotas Europinio lygmens miestas - sostinè ne tik su visais būtiniausiais tokio tipo miesto atributais, socialines idejjas ir galią reprezentuojančiais objektais ir viešosiomis erdvemis, bet ir su jo turiniu - miesto kultūra ${ }^{3}$. Visais laikotarpiais miestas kaip reiškinys ir objektyvi tikrovè niekada nebuvo statišku dariniu. Tai nuolat kintanti ir besitransformuojanti dinaminè sistema. Todèl dèsninga, kad jo plètros ir kaitos rezultatai aiškiausiai yra matomi ne tik didejant arba plètojantis teritorijai $i$ „,išorę“, bet ir keičiantis miesto „vidaus“ arba jo viešosioms erdvèms. Kaip tik čia paminètu laikotarpiu, kai buvo svarbu įtvirtinti ir išreikšti nacionalinès valstybės ideologiją. Taip daugumos Lietuvos miestų pagrindinèse viešosiose erdvèse ir ypač aikštėse atsirado naujų nacionalinę idejją reprezentuojančių paminklų, o ir pačios erdvès buvo pertvarkomos iš esmès naujai jų estetiniam vaizdui sukurti naudojant nacionalinius motyvus (1 pav.).

\footnotetext{
${ }^{3}$ Šia tema yra parašyta nemažai. Apie reprezentacines Kauno aikštes yra rašiusi J. Kančienè (2006). Apie kultūros gyvenimą, autoriaus požiūriu, vertingiausia monografija yra J. Mulevičiūtès „Modernizmo link. Dailès gyvenimas Lietuvos Respublikoje 1918-1940“. Kaunas, 2001.
} 


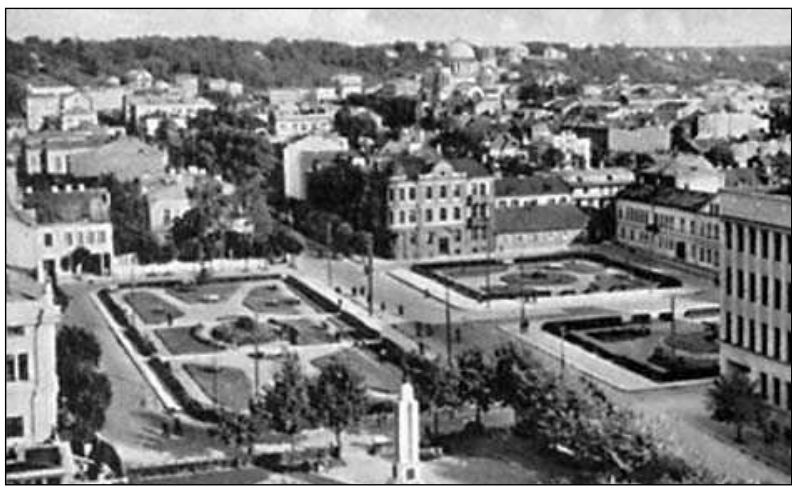

1 pav. Vienybès aikštè Kaune. Apie $1939 \mathrm{~m}$.

(iš R. Viedrynaičio (sud.) knygos „Kaunas. Istorija, praeitis, dabartis". Kaunas, 2006). Vytauto Augustino nuotr. 1939 m. Atvirukas

Fig. 1. Kaunas Union Square in 1939

Labai panaši - gerokai pagreitinta - miesto raida vyksta pastarąji dešimtmetị, kai nuo apytiksliai 1995 iki 2008 metu ir sostinè, ir kiti didieji Lietuvos miestai auga ir vystosi labai intensyviai. Miesto viešųju erdviu - ir ypač pagrindinių miesto aikščiu - atveju yra kiek blogiau. Paskutinis žymus jų formavimo laikotarpis apima Sovietinès okupacijos laikus, o per pastaruosius 18 nepriklausomybès metų suformuotos arba pertvarkytos tik keletas aikščių, kurios nèra pagrindinès (pavyzdžiui, Lietuvininkų aikštė Klaipèdoje arba Savivaldybès skverelis netoli Prisikèlimo aikštės Šiauliuose). Kaip išskirtinis pavyzdys paminètina Laisvès aikštė Panevėžyje, tačiau šis atvejis savo sprendimų apimtimi ir rezultatu iš esmès nesprendžia urbanistinių erdvès sutvarkymo problemų, o tik naujojo monumento statymo ir ji supančios aplinkos pritaikymo uždavinius. Tačiau pagrindinès didžiųjų miestų aikštės tebèra nesuformuotos. Išnykus pagrindiniam jas identifikuojančiam elementui - monumentui šios aikštès kaip visuma yra nepabaigtos ir neaiškios. Daugeliu atvejų savo sandara ir erdvės kompozicijos dèsniais jos aiškiai perteike ir buvusią reprezentacinę paskirtį, ir socialinę ideologiją, akcentuojant patị monumentą. Jam išnykus ir erdvès morfologijai nepakitus, tokių aikščių situacija liko ir tebèra neaiški. Taigi net ir preliminariai matyti, kad paliestas pagrindiniu miesto aikščių formavimo klausimas yra sudètingas ir nevienalytis. Jam spręsti reikia ir gerokai daugiau laiko diskusijoms, ir papildomų tarpdisciplininių studijų bei mokslinių tyrimų. Viename straipsnyje dèl ribotos apimties tokio masto problema negali būti išspręsta. Todèl šio teksto tikslas - trumpai apžvelgti kai kurias, kiek aiškiau matomas minètų miesto aikščių formavimo tendencijas ir problematiškiausius pavyzdžius (kartais rezultatus) kiek platesniame teoriniame diskurse, atkreipiant dèmesị tiek ị pačios viešosios erdvès sampratos kaitą skirtingais aspektais, tiek ir ị tipologinès kaitos dèsningumus (be kita ko, būdingus ir mūsų laikotarpiui), stengiantis kiek įmanoma sisteminti medžiagą. Tokia apžvalga galètų padèti diskusijoms tiek aktualizuojant neaiškumo problemą bei jos socialini aspektą, tiek ir keliant klausimus ir uždavinius tolesnèms studijoms bei tyrimams šia tema. Tam tikros idejjos ir retesni rezultatai rodo šiandien vyraujančias tendencijas skirtinguose lygmenyse. Jas aptariant, analizuojant ir verifikuojant, sudètinga problema gali atsiskleisti kitu aspektu. Ir tik visiškai perpratus viešosios erdvès fenomeno reiškinius bei struktūrą bus įmanoma suformuluoti aiškius reikalavimus ir kriterijus erdvèms formuoti.

\section{Kintantys socialiniai reikalavimai ir miesto viešųjų erdvių samprata}

Anksčiau paminèta neaiški viešųjų erdvių situacija akivaizdžiai reikalauja papildomo dèmesio, nes tai, kad bemaž du dešimtmečius nevyksta plètra, turi neigiamo ar tiesiog reiškinio bruožų. Tai, kad tinkamų sprendinių nepavyksta surasti taip ilgai, preliminariai gali indikuoti keletą dalykų:

1) nepakankamą problemos pažinimą ar suvokimą, $o$ tai neleidžia tinkamai suformuluoti urbanistinius ir architektūrinius uždavinius;

2) finansinę ir politinę sprendžiančių miesto viešųjų erdvių plètros problemą socialinės galios subjektų negalią;

3) bendrų ir aiškiai suformuluotų kriterijų, kuriais galima būtų vadovautis, kuriant erdvés morfologiją ir ja išreiškiamą semantinę gramatiką, trūkumą.

Pirmuoju atveju galime matyti, kad kai kada, skelbiant tokių viešųjų erdvių sutvarkymo konkursus, sąlygose formuluojami uždaviniai yra gerokai per platūs ir net abstraktūs, sujungiantys ir urbanistinius, ir architektūrinius, ir skulptūrinès plastikos klausimus ${ }^{4}$. Antruoju atveju tikètina, kad pagrindiniai miesto ateitị planuojantys ir aktyviausiai jị kuriantys socialinès galios subjektai - privatus kapitalas ir ypač savivalda (labai retai - valstybè) - skirtingai suvokia miesto viešosios erdvès reikšmę bei svarbą tiek miestui, tiek ir jo

\footnotetext{
${ }^{4}$ Čia turimas omenyje itin politizuotas Lukiškiu aikštès konkursas Vilniuje ir jo raida. Kai nesutariama dèl aikštès statuso net politiniame lygmenyje (žr. Vyriausybès nutarimą LR Seimo 1999 m. vasario 11 d. nutarimas Nr. VIII - 1070. "Dèl valstybès sostinèje esančios Lukiškių aikštès funkcijų", Seimo $2000 \mathrm{~m}$. spalio $17 \mathrm{~d}$. priimtas ịstatymas „Dèl Lukiškių aikštės Vilniuje“, kurị Prezidentas V. Adamkus vetavo).
} 
sociumui, nevienodai pajègia ir nori jas keisti. Viena vertus, savivalda Lietuvoje spartaus arba „laukinio“ kapitalizmo miesto raidos sąlygomis neturi pakankamai galių ir patirties demokratiškomis priemonemis ir produktyviai plètoti tokių probleminių miesto viešųju erdvių. Kita vertus, reikia prisiminti, kad tiek pačios savivaldos, tiek ir viešųų erdvių formavimo tradicija Lietuvoje buvo nutraukta ir naikinama daugiau nei pusę amžiaus okupacijos, o tradicijos vykdyti toką veiklą i ją įtraukiant kuo įvairesnes visuomenès grupes Lietuvoje apskritai nèra. Trečiuoju atveju visuomenè, palaipsniui kisdama pati, keičia miestus, požiūrị i viešąsias erdves (ir aikštes) ir neretai tikisi skirtingo nei iki tol erdvinès morfologijos išreiškiamo semiologinio teksto (kalbant F. Choay (Шoe 1978) terminais), kuris būtų perskaitomas ir laikomas priimtinu daugumai. Neretai tas pakitęs požiūris bei aktuali viešosios erdvès samprata ir lemia viešosios erdvés naudojimą bei nenaudojimą. Tai susiję ir su galimais jos naudojimo (paskirties) scenarijais, kurie paprastai atitinka jos kompozicinę ir morfologinę sandaras bei išreiškia minètą tekstą. Kuo daugiau monologo (ne polilogo) požymių jis turi, tuo siauriau toks semiologinis tekstas yra perskaitomas ir, dèsningai, jis būna priimtinas tik mažumai. Tačiau kai erdve yra neaiški iš esmès, be aiškios paskirties ir nesuformuota, jos erdvinès semantikos interpretacijų laukas taip pat būna siauras ir jos naujo panaudojimo galimybès, iš esmès netransformuojant to lauko, lieka labai mažos.

Kalbant platesne prasme, visuomenès mentaliteto (Peter Dinzelbacher (1998) terminais) sociokultūrinio konteksto charakteristikai ${ }^{5}$ šiandien būdinga tam tikra visuomeniškumo ir privatumo paradigmų niveliacija. Šią problemą aptaria ne vienas autorius ${ }^{6}$. Tai reiškia, kai ir idejiniame filosofiniame lygmenyje, ir kasdienèse sociumo patirtyse privatumo ir visuomeniškumo (arba viešumo) ribos ne visada yra aiškios ar aiškiai apibrèžtos. Jos tradiciškai kinta, keičiantis socialinio mentaliteto archetipms. Kalbant apie miestą ir jo viešųjų erdvių sistemą, atsiranda panaši sampratos sumaištis, kai neretai viešąja erdve vadinami objektai ir urbanistiniai dariniai, kurie iki šiol nebuvo suprantami kaip tradicinè miesto viešoji erdvè. Kartais tai - pastatai, tokie kaip kino teatras, biblioteka ir panašūs, arba tiesiog visuomeniniai pastatai, kurie igauna arba yra

\footnotetext{
${ }^{5}$ Mentaliteto sociokultūrinio konteksto charakteristika čia turima omenyje viena iš keturių - Vieta, Tvarka, Mentalitetas, Kultūra ir jos raiškos formos (Grunskis 2005).

${ }^{6}$ Visuomeniškumo ir privatumo santykio kaita nagrinèja jau minètas Peter Dinzelbacher bei kiti autoriai (žr. Weintraub, Kumar 1997).
}

igavę sociokultūrinio reiškinio bruožų, o socialinèje atmintyje yra suvokiami kaip kultūros sklaidos bei visuomeninio gyvenimo židiniai ir viešojo gyvenimo erdvès (čia prisimintinas "Lietuvos" kino teatro pavyzdys Vilniuje). Viena vertus, tik peržvelgiant pastarųjų kelerių metų polemiką ir diskusijas apie viešąsias erdves bei viešąji interesą, krenta i akis faktai, kad neretai viešaja erdve vadinama kur kas daugiau, nei tai yra iš tikrųjų ir minètasis pavyzdys tai aiškiausiai liudija. Šią sampratos problemą padeda paaiškinti ir kitas - erdvès morfologinis aspektas. Nes tam tikros sumaišties i viešosios erdvès bei aikštės sampratą įneša ir skirtingi požiūriai ị pačią miesto erdvès (Urban space) morfologiją. Esama kelių pagrindinių požiūrių - tradicinis ir modernistinis. Pirmajam atstovauja Collin Row, Aldo Rossi su italų racionalistų mokykla, broliai Rob ir Leon Krier. Antrajam - Le Corbusier, F. L.Wright ir kiti šios tradicijos sekejjai. Iš esmès šie du požiūriai bei jų taikymas, formuojant ir miestą, ir jo viešąsias erdves duoda visiškai skirtingus erdvinius bei struktūrinius miesto rezultatus, aišku, keisdami ir patị miesto vaizdą. Tradiciniam požiūriui būdingas tradicinių priemonių ir morfologinių elementų plètojimas, modernistiniam būdingas tam tikras santykis su istorija ir inovacija. Pirmasis kuria miesto struktūrą ir erdvę, kuri savo morfologiniais požymiais yra artima tradiciniam istoriniam miestui, antrasis - formuoja laisvai erdveje esančius objektus (ne statinius), kurie ignoruoja urbanistinị kontekstą, jo audinị ir morfologinius dèsnius. Taip miesto erdvè (Urban space) su savo struktūriniais morfologiniais elementais - sklypais (morfotipu), užstatymu ir kvartalų pobūdžiu, gatviu tinklu ir erdvemis tarp užstatymo - traktuojama skirtingai, taigi ir pačios viešosios erdvès, ir aikštės samprata kinta. Neretai atsitinka, kad aikšte vadinami ir tiesiog neužstatyti plotai, ir net transporto žiedai. Tai susiję su minèta modernistine miesto viešosios erdvès sampratos ir miesto morfologinès struktūros formavimo tradicijų kaita. Pavyzdžiui, pagal modernistinę sampratą miesto viešosios erdvès tipas - aikštè - neprivalo būti uždaros struktūros, suformuota užstatymo (tai yra struktūrins ir erdvinis uždarumas nèra būtinas), bet tai gali būti bet koks kitas kiek aiškiau išreikštas erdvės plotas su erdvejje dominuojančiu objektu, kuris nebūtinai yra pastatas, arba be jo. Taigi aikštemis vadinami ir plotai prie didelių sporto kompleksų, kurie iš esmès yra tiesiog tuščias plotas, paprastai būtinas tokiam pastatui. Šiuo požiūriu įdomus pavyzdys galètų būti Popiežiaus Jono Pauliaus II-ojo aikštė Vilniuje, kuri iš esmès nėra suformuota miesto viešoji erdvè jokiu požiūriu ir nèra aišku, ar tai automobilių stovejimo aikštelè, ar tiesiog 
transporto žiedas. Todèl akivaizdžiai šios erdvès morfologinès savybės prieštarauja įvardintai paskirčiai ir miesto viešąja erdve - aikšte - yra vadinamas tiesiog tuščias ir neaiškus plotas?

\section{Naujosios miesto viešujų erdvių tipologijos}

Tradicinė miesto viešųjų erdvių sistema nuolat kinta ir kokybiniu, ir struktūriniu, ir kiekio požiūriu. Formuojantis ir plintant miestui ji tampa sudètingesnè, polifunkciška ir daugiasluoksnè. XIX a. vykstant urbanizacijai buvo sukurta ir išplètota daug miesto viešųjų erdvių, tarp jų ir viešosios erdvès visuomeniniuose pastatuose (tradicija, siekianti Antiką ir primiršta kai kuriais miesto raidos laikotarpiais). Išvystyta statybos technika ir technologija leido palyginti nebrangiai lengva stogo konstrukcija perdengti didelius plotus, o tai kartu leido formuoti naujus miesto viešųjų erdvių tipus pastatuose. Taip atsirado pasažas, atriumas, dengtos prekybos bei parodų salès ir panašiai. Taip pat tradiciné miesto viešujų erdvių sistema buvo papildyta naujais viešųjų erdvių potipiais - pavyzdžiui, bulvaras - tradicinè gatvès miesto viešoji erdvè su parko morfologiniais elementais - apželdinimu; krantinè - su apželdinimu arba be jo. Čia minimo laikotarpio miesto viešųjų erdvių formavimui būdingas bruožas yra tai, kad viešosios erdvès, atskiriant ịvairias jų paskirtis, yra labiau nei iki tol sukultūrinamos ir estetizuojamos apželdinant. Taip pat atsitinka ir su aikštėmis, kurios palaipsniui tampa skverais. Taip aikštè, netekdama funkcijų ir paskirčių ịvairovès, yra sukultūrinama bei estetizuojama ir palaipsniui igauna parko morfologinių bruožų. Pirmapradè - tradicinè - jos paskirtis ir polifunkciškumas yra idèjiškai ir struktūriškai perorganizuojami pagal naujus aktualius visuomenès poreikius ir galiojančią estetinę doktriną. Naujieji miesto viešųjų erdvių dariniai - tokie kaip turgūs lieka aiškiai monofunkciški, atitinkantys utilitarius ir higienos reikalavimus (pavyzdžiui, Lukiškių aikštės

\footnotetext{
${ }^{7}$ Čia primintinas tradicinès miesto viešosios erdvès apologeto Camillo Sitte aikštès apibūdinimas. C. Sitte teigè, jog tuščias plotas dar negali būti vadinamas aikšte. Paminètas pavyzdys akivaizdus šios minties irodymas. Jis taip pat parodo, kad ir su labai geromis intencijomis, vien tik ịvardinus erdvès paskirtị, tuo pat metu jos nesuformavus, gaunamas bene priešingas rezultatas. Tačiau iš esmès tam tikro konflikto prado esama ir pačiame viešosios erdvès fenomene, nes jis reprezentuoja kur kas daugiau nei fizinę tam tikros miesto erdvès funkcija ar paskirti mieste. Iš miesto viešosios erdvès fenomeno ir tradicijų raidos matyti, kad kaip tik miesto viešosiose erdvėse vyksta arba yra ịprasminami ivvairiausi socialiniai reiškiniai ar ịvykiai ir kad tai kur kas daugiau nei fizinè erdvès riba ar jos paskirtis. Tai fenomenas, akumuliuojantis reiškinius ir pats turintis reiškinio bruožų.
}

turgus XIX a. pabaigoje - XX a. pradžioje). Parkai, kurie tapę tikra miesto viešąja erdve ir priklauso visam miestui (nebe elitui), nuo XVII a. Vakarų Europoje ir nuo XIX a. Lietuvoje vystomi laikantis panašios erdvès estetizavimo ir kultūrinimo doktrinos.

Panašiai kaip miesto raidos istorijoje pastarąji dešimtmetị miestų viešųų erdvių tipologinè raida irgi kinta. Čia susiduriame su reiškiniu, kai Lietuvos miestuose dideli visuomeniniai pastatai - prekybos ir pramogų centrai - tampa miesto viešųjų erdvių pakaitalu. Juose sutelkiama daug iki tol tradicinių miesto centrui būdingų funkcijų ir net miesto viešujų erdvių (tai prekybinè gatvè, lokali miesto aikšte (plazza) ir panašiai). Lietuvos kontekstui būdinga, kad tokio tipo ir dydžio visuomeniniai pastatai prekybos pramogų centrų pavidalu atsirado miesto centro zonoje arba labai arti jos. Ju dislokacija ir pobūdis neretai sukelia priešpriešą tradicinei miesto struktūrai ir tradicinei miesto visuomeninių erdvių sistemai, dažnai ją dubliuoja ir net jai kenkia. Be to, toks reiškinys, kai tradicinės miesto viešosios erdvès atsiranda visuomeniniuose pastatuose, sukuria tam tikrą miesto tikroves pakaitalą ir alternatyvą. Ilgainiui tokie dariniai perima miesto centro funkcijas ir tikrasis tradicinis miesto centras su savo bendruomenine kultūra ir lokalia gyvensena palaipsniui atrofuojasi. Toks virtualumas iš esmès prieštarauja tradicinei miesto ir jo viešųjų erdvių raidai. Paskutinè sparti urbanizacijos banga Lietuvos didžiuosiuose miestuose kai kuriais atvejais lemia laikiną kai kurių tradicinių miesto viešųjų erdvių atrofiją. Ryškiausias pavyzdys - Laisvės alèja Kaune, kai pastačius „Akropolio“ prekybos ir pramogu centrą daugelis prekybos ir kitų miesto visuomeninių funkcijų tiesiog persikèlè $\mathfrak{i} j i$, o tradicinè miesto viešoji erdvè - pagrindinè prekybinè miesto gatvè (bulvaras) liko bemaž tuščia ir yra kur kas mažiau naudojama. Tačiau bendruoju atveju negalima teigti, kad miesto viešosios erdvès nyksta. Taip nèra. Jos daugeliu atveju tiesiog nèra plètojamos ir formuojamos ne taip intensyviai, kaip formuojamas ir plètojamas miestas ar jo dalys. Preliminariai galima teigti, kad demesys miesto centro ir jo infrastruktūros vystymui neatitinka jo viešųjų erdvių sistemos vystymo, nors tradiciškai viena be kito egzistuoti negali ar bent jau neturètų. Pavyzdžiui, Vilniaus miesto krantinès viešoji erdve panašesnè i dykrą nei ị miesto prie vandens krantinę ir tokių pavyzdžių yra daugiau. Bendrai atrodo, kad socialinès galios subjektas - Savivaldybè, kurio sprendimu turi būti formuojamos tokios erdvès, kol kas yra silpnas, o Socialinès galios subjektas - privatus Kapitalas, arba finansinis elitas, suvokiantis visuomeniškumo komer- 

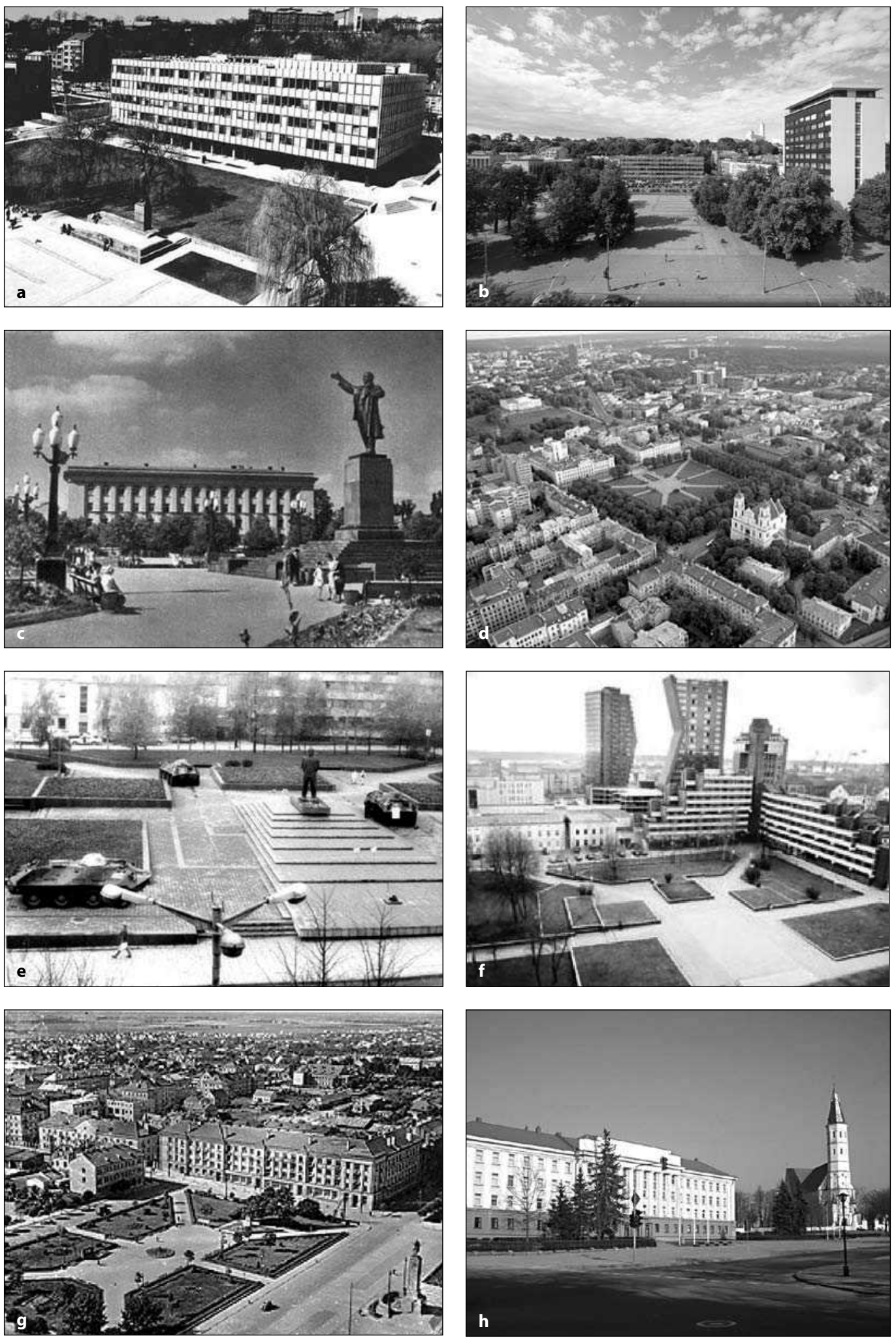

2 pav. Pagrindinių reprezentacinių miesto viešuju erdvių transformacijų pavyzdžiai: a, b - Vienybės (buvusiojo Janonio) aikšte Kaune; c, d - Lukiškiu (buvusioji Lenino) aikšte Vilniuje; e, f - Atgimimo (buvusioji Lenino) aikšte Klaipèdoje; $\mathrm{g}, \mathrm{h}$ - Prisikèlimo (buvusioji Pergalès) aikštè Šiauliuose

Fig. 2. Examples of transformations of the main representative public spaces: $a, b$ - Union (former Janonis') Square in Kaunas; $c, d$ - Lukiškių (former Lenin's) Square in Vilnius; e, $f$ - Revival (former Lenin's) Square in Klaipèda; $\mathrm{g}, \mathrm{h}$ - Resurrection (former Victory) Square in Šiauliai 
cinę naudą viešąją erdvę perkelia ị pastatus, i jų vidines erdves ir tam tikra prasme jas privatizuoja.

Kalbant apie naujus miesto viešųjų erdvių tipus ir jų kaitą, būtina pažymèti, kad XX a. viduryje Lietuvoje buvo naujai išplètotos valstybinès reprezentacinès miesto viešosios erdvès tipas, kai kiekviename didžiajame Lietuvos mieste buvo suformuota sava Lenino arba komunistinę ideologiją reprezentuojanti aikštè. Tokio reprezentacinio tipo aikštès miesto raidos istorijoje egzistavo visada, tik jos skyrèsi skirtinguose kontekstuose tiek dydžiu, tiek ir svarba (hierarchija) mieste, iš vieno tipo virsdamos kitu, arba, pakeitus aikštès paskirtị ir morfologiją, tapdavo svarbiausios. Tačiau daugelio tokių aikščių semiologinis tekstas ir erdvès morfologija yra panašūs, perteikiantys panašia erdvès gramatika tam tikras tuometines socialines vertybes ir ideologiją. Tokios aikštés neretai būna didelio ploto ir suorganizuotos, taikant patị parasčiausią (jei ne primityviausią) erdvės kūrimo metodą. Semiologinis tekstas tokiais atvejais būna itin aiškus ir vienareikšmis. Jam išreikšti taikomi patys paprasčiausi ir sociumui suprantami erdvès komponavimo metodai (veidrodinè simetrija, itin stambaus mastelio urbanistinès ašys ar kitokia geometrija, stambūs kompleksai ir panašiai), kuo aiškiausiai reprezentuojantys galią ir nepaliekantys erdvès kokioms nors kitokioms interpretacijoms ar tekstams. Tai yra galios reprezentavimo mieste ir jo viešosiose ervėse (ir ypač aikštėse) tradicija, beveik visada paremta kokia nors ideologija ir poreikiu ją išreikšti, kuris viršija bet kokius kitus poreikius. Taip pat ir čia primintu sovietiniu laikotarpiu tradicinis daugiafunkcès aikštės viešosios erdvès tipas neteko savo aktualumo bei paskirties ir palaipsniui aikštėms buvo suteikiama parko elementų, taip jos buvo dar labiau estetizuojamos ir „sukultūrinamos" ${ }^{\text {"8 }}$.

\section{Aikščių viešųjų erdvių formavimo tendencijos ir jų idèjos}

Per pastaruosius 18 nepriklausomybės metų buvo keletas bandymų architektūriniais konkursais spręsti anksčiau buvusių ideologinių miesto viešųjų erdvių aikščių - pertvarkymo klausimus. Šiais metais tas poreikis ypač suaktualejjo. Ir jis jau igavo reiškinio požymių, kai svarstoma buvusių Administracijos šventovių

\footnotetext{
${ }^{8}$ Atskiros studijos šiuo atveju reikalauja parkai. Idomu, kad šio laikotarpio miesto parko viešosios erdvès formavimas turi kri minalo elementą. Juk neretai miesto parkai buvo formuojami buvusių kapinių vietose, jų net neiškeliant, bet tik nugriaunant antkapius.

${ }^{9}$ Apie tokius konkursus rašè K. Šešelgis (1997), D. Linartas (2009), „Archiforma“ (1999) ir kiti.
}

ir valstybės galią reprezentuojančių erdvių kokybės klausimas, net jei tai vyksta tik idejjiniame lygmenyje. Bendrai trečioji Lietuvos urbanizacijos banga viešųjų erdvių formavimą veikè gana lètai ir neintensyviai. Sunku būtų surasti pavyzdžių, kurie rodytų, kad viešosios erdvès buvo performuotos ar transformuotos iš esmès, pakeičiant erdvės morfologiją. Nèra rezultatų ar požymių, aiškiai rodančių, kad miesto viešųjų erdvių formavimo procesas vyksta ir turi kokių nors esminių kokybinių kaitos rodiklių. Nemaža pavyzdžių, kai viešoji erdvė yra iš dalies pertvarkoma „koreguojant" grindinio dangos kokybę arba pakeičiant vieną monumentą kitu. Bendra situacija turi aiškių stagnacijos bruožų. Galime matyti kelis pagrindinius ir esminius pastarojo dešimtmečio miesto aikščių erdvių formavimo bruožus - dekonstrukcija ir pakeitimas. Dekonstrukcija, kai daugelis reikšmingiausių iki tol miesto aikščių neteko savo esmę išreiškiančio elemento - ideologinio monumento. Lenino paminklai išnyko visose reprezentacinèse ir socialistinę ideologiją žymëjusiose aikštėse. Tačiau juos panaikinus nieko naujo iš esmès pasiūlyta nebuvo. Pakeitimas (substitution) - kitas, svarbus paminèti, miesto viešųjų erdvių formavimo bruožas - tai naujo monumento kūrimas jau egzistuojančiose erdvèse, kai nekeičiant viešosios erdvės kompozicinio principo joje pastatomas monumentas, nesprendžiant jo ir ji supančios aplinkos santykio klausimų ${ }^{10}$ (3, 4 pav. - buvusi Černiachovskio aikštè ir dabartinè Savivaldybės aikštė Vilniuje).

Apžvelgus pastarųjų metų miesto viešųjų erdvių projektinius sprendinius ir diskusijas apie juos išskirtinos kelios pagrindinès tendencijos:

a) Daugelis realizuotų svarbiausių miesto viešųjų erdvių pavyzdžių apsiriboja sprendinio lokalumu, kai iš esmès nekeičiama erdvès kokybè - jos parametrai ir erdvès morfologija, kreipiant demesị ir keičiant tik apdailą, nekoreguojant erdvès formavimo ir kompozicinio principo. Esama tik keletas realizacijų, kuriose naujasis monumentas ir naujai suformuota ji supanti erdvė sudaro užbaigtumo ìspūdị ir savo morfologija bei semiologiniu tekstu perteikia aktualias socialines vertybes.

b) Kai kuriami nauji monumentai buvusių monumentų arba beveik jų vietoje, iš esmès pakeičiama dominantès kokybè ir skulptūrinè išraiška, bet ne erdvès kokybè iš esmès.

\footnotetext{
${ }^{10}$ Monumentas ir ji supanti aplinka - viešoji erdve, veikianti kaip vientisa sistema, savo kompozicija ir erdvés organizavimu perteikianti tam tikras nuostatas, aktualias socialines vertybes, idéjas ar ideologiją.
} 


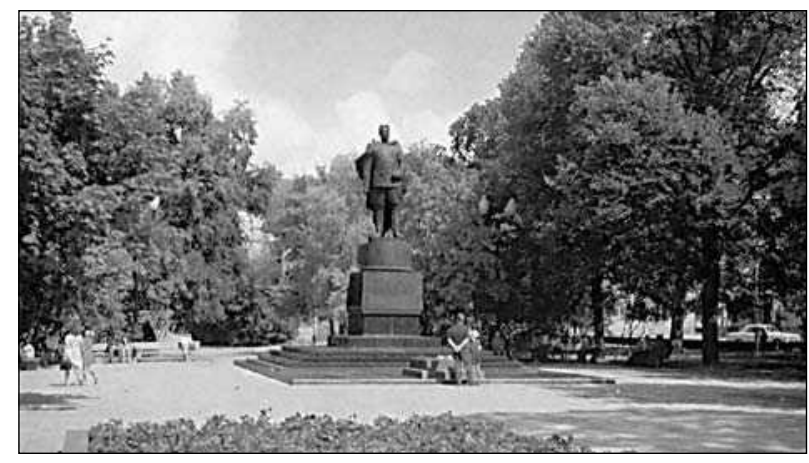

3 pav. Černiachovskio antkapinis paminklas aikštèje apie $1980 \mathrm{~m}$.

Fig. 3. Monument to General Cherniachovsky on his grave in the city square

c) Naujausi miesto viešųjų erdvių projektiniai siūlymai (žr. Lukiškių ir Vienybès aikščių konkursinius projektus adresu www.architektusajunga.lt) meninès kokybės aspektu neretai yra labai aukšto lygio, dažniausiai išreiškiantys pamatines Vakarų Europos miesto aikščiu tradicijas.

Tačiau užduočių nekonkretumas ir keliamų uždavinių interpretacijų ívairovė neretai lemia sunkumus atrenkant tinkamiausius sprendinius. Kartu visuomenè, kuri iš dalies sprendžia būsimų erdvių likimą, labiau orientuojasi i aiškiausiai jai suprantamus (kartais ir primityviausius) semiologinius tekstus, išreikštus erdvès morfologija ir kompozicinèmis priemonèmis, kurios neretai primityviai pakeičia tik „fasadinę “ išorinę viešosios erdvès pusę, bet ne pačią erdvę iš esmès. Tai rodo, kad šiandienis socialinis mentalitetas dar nèra pakitęs ir veikia tam tikri netolimos praeities mentaliniai recidyvai ir kad jis yra orientuotas i i praeitit, ne i ateitị. Naujausių projektų ir idejjų pavyzdžiuose, siūlomuose buvusioms reprezentacinėms Lenino aikštèms, galima išskirti itin pozityvų bruožą. Jau atsiranda idèjų bei pasiūlymų, kurių autoriai sugeba konceptualizuotai ir atsietai vertinti neseną praeitị, siūlo universalius ir kartu įtaigius viešųjų erdvių ịvaizdžius, išvengdami dekoratyvumo, pompastikos, perdèto moralizavimo.

\section{Apibendrinimas}

Miestai išreiškia juos sukūrusias visuomenes. Jų viešųjų erdvių formavimo tradicija yra tokia pat sena kaip ir patys miestai. Tai, kaip formuojamos miesto viešosios erdvès ir kaip jos naudojamos, minètą ryšį dažniausiai tik patvirtina. Jų formavimas dėsningai neatsiejamas nuo sociokultūrinio konteksto ir jo charakteristikų. Visuomenei keičiantis, keičiasi požiūriai ir ị miestą bei

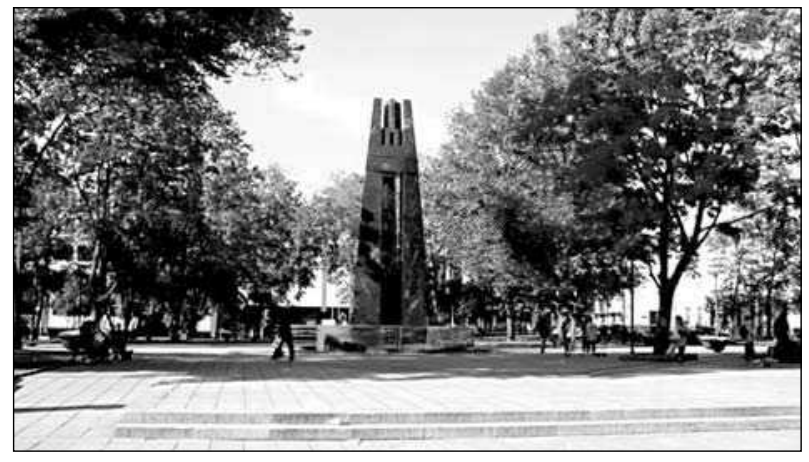

4 pav. Kudirkos paminklas Savivaldybès aikštèje

Fig. 4. Monument to Vincas Kudirka. Current view

jo formavimą, ir ị tradicijas bei principus, pagal kuriuos reikia jị plètoti, ir ị viešąsias erdves bei jų reikšmę. Kartu kinta ir šių dalykų sampratos, lemiančios miestų išvaizdą, morfologiją ir semiologinị tekstą. Tokia nuolatinè kaita yra pats stabiliausias ir miesto, ir viešosios erdvès - aikštès - fenomenų bruožas. Kaita leidžia plètotis ir miesto viešjųjų erdvių sistemai, joje atsiranda naujų viešųų erdvių tipų ir potipių ir transformuojasi seni. Panaši kaita būdinga ir daugeliui buvusių pagrindinių reprezentacinių miesto aikščių, kurios, pašalinus pagrindinius jų elementus - ideologinius monuentus, šiandien tebera nesuformuotos. Jų formavimo procesui kol kas būdingi stagnacijos požymiai, nes objektyvių formavimo rezultatų dar nèra. Apžvelgus 1990-2009 m. laikotarpio miesto viešųjų erdvių ir aikščių formavimo pavyzdžius išskirtinos tik kelios pagrindinès tendencijos:

1) dekonstrukcija ir neaiškumas, kai pasikeitus sociokultūriniam kontekstui ir socialinei ideologijai iš pagrindinių reprezentacinių miestų aikščių buvo pašalinti ankstesniąją ideologiją ịprasminę monumentai. Tačiau nauji sprendiniai iki šiol nèra surasti. Kadangi šių erdvių performavimo procesas yra beveik sustojęs, esami rezultatai yra neaiškūs;

2) pakeitimas, kai vietoje ankstesnių monumentų, jų arba beveik jų vietoje statomi naujieji, iš esmès nekeičiant viešosios erdvės kompozicinės kokybės;

3) naujausieji buvusių pagrindinių reprezentacinių miesto aikščių pasiūlymų konkursiniai sprendiniai yra neretai labai aukštos meninès vertès, savo erdvès morfologija ir semiologiniu tekstu perteikiantys ir aktualias, ir universales socialines vertybes, išvengiantys perdetos pompastikos ir moralizavimo. 


\section{Literatūra}

Choay, F. 1996. The Rule and the Model: On the Theory of Architecture and Urbanism. Cambridge: MIT Press.

Dinzelbacher, P. (sud.). 1998. Europos mentaliteto istorija. Vilnius: Aidai (lietuviškas vertimas iš Europäische Mentalitätgeschichte Hauptthemen in Einyeldarstellungen. Stuttgart: Kröner, 1993).

Grunskis, T. 2005. Pastabos apie Vilniaus miesto raidą. Vilnius 1900-2005. Naujosios architektūros gidas. Vilnius: Architektūros fondas, 4-7.

Kančienė, J. 2006. Laikinosios sostinès reprezentacinès aikštès, Archiforma 3(35): 72-80. doi: 10.3846/1392-1630.2009.33.39-47

Linartas, D. 2009. Sovietinio laikotarpio architektūros konkursų raidos apžvalga, Urbanistikia ir architektūra 33(1): 39-47.

LR Seimo 1999 m. vasario 11 d. nutarimas Nr. VIII - 1070 Dèl valstybès sostinèje esančios Lukiškiu aikštès funkciju.

Lukiškiu aikštès Vilniuje sutvarkymo architektūrinis konkursas. 2009 [interaktyvus]. Lietuvos architektų sąjungos tinklapis [žiūrèta 200909 07]. Prieiga per interneta: $<$ http://www.architektusajunga.lt/ LT.php?content=page\&Id $=587>$.

Mikučianis, V. 1997. Atsiminimai apie pokarinio Vilniaus konkursus, Archiforma 97/3: 74-80.

Miškinis, A. 1991. Lietuvos urbanistika: praeitis, dabartis, ateitis. Vilnius.

Mulevičiūtè, J. 2001. Modernizmo link. Dailes gyvenimas Lietuvos Respublikoje 1918-1940. Kaunas.

Nepasirašytas. Dèl Lukiškiu aikštès Vilniuje ISTATYMAS [interaktyvus] [žiūrèta 200909 07]. Prieiga per internetą: $<$ http://www3.lrs.lt/pls/inter3/dokpaieska.showdoc_l?p_ id $=108642>$.

Sitte, C. 1889. Der Städtebau nach seinen künstlerischen Grundsätzen. Vertimas ị anglų kalbą: City Planning According to Artistic Principles (New York: Random House, 1965). Vertimas į rusų kalbą: К. Зитте. Художественные основы градостроительства (Москва: Стройиздат, 1993).

Šešelgis, K. 1996. Lietuvos urbanistikos istorijos bruožai: nuo seniausiu laiku iki 1918 m. Vilnius: Mokslo ir enciklopedijų l-kla.

Šešelgis, K. 1997. Vilniaus miesto Lukiškių aikštès formavimo projektai, Urbanistika ir architektûra 24(2): 32-53.

Tarptautiniu žodžiu žodynas. 2004 [interaktyvus] [žiūrèta 200909 07]. Prieiga per internetą: <http://www.zodynas. $\mathrm{tk} />$.

Trimakas, R.; Meilius, K. 2007. Contemporary transformation of personal status: paradigm of systemic crisis and the quest for solution, SOTER - Journal of Religious Science 24: $75-88$.

Viedrynaitis, R. (sud.). 2006. Kaunas. Istorija, praeitis, dabartis. Kaunas: Šviesa.

Vienybès aikštès sutvarkymo konkursas. 2008. Lietuvos architektų sąjungos tinklapis [žiūrèta 200909 07]. Prieiga per internetą: <http://www.architektusajunga.lt/LT.php?c ontent $=$ page $\& \mathrm{Id}=562 \&$ PHPSESSID $=66390778 \mathrm{e} 5 \mathrm{~d} 2 \mathrm{f} 0560$ f787ffd6dda2a30>.
Weintraub, J.; Kumar, K. 1997. Public and Private in Thought and Practice. University of Chicago Press.

Шое, Ф. 1978. Заметки по поводу городской семиологии, Современная архитектура 1: 5-6.

\section{ON SOME CONTEMPORARY SQUARE FORMATION TRENDS IN LITHUANIA}

\section{T. Grunskis}

Summary. Twenty years of development in a town's history is not a long period of time especially provided that the sociocultural context conditions for such a development may be defined as "favorable" or "normal". Under conditions of accelerated urbanization, however, when a town is undergoing particularly rapid development, which is even more encouraged by conditions of the context, the whole situation looks by far worse. Throughout the 20th century Lithuania underwent two stages of such an accelerated urbanization. During the first stage of such an urbanization, at the time of the first Lithuanian Republic (1918-1940), the concept of a national capital was conceived and rapidly developed. As soon as it was realized within 20 years in Kaunas, a capital city of European level was formed not only with all the attributes characteristic of a town of the type, but also with its content - urban culture. It is a consistent pattern that the results of urban development can be seen most clearly not only in expansion of a town's territory (outward development), but also through changes in its "inner" or public spaces. Within the aforementioned period, when it was so important to entrench the ideology of the nation state, new monuments representing a national idea occurred in public spaces (squares) of major Lithuanian towns, and even such spaces were reconstructed in a new manner (Fig. 1). Similar urban development - although on a fairly accelerated scale - has been carried out during the recent decade, when starting from 1995 to 2008 the capital city and other major Lithuanian towns were growing and developing extremely extensively. As for the changes in urban public spaces, the situation is far worse. The last significant period of public space formation goes back to the soviet occupation times, and within recent 18 years of independence just a few town squares have been formed or reformed. The present situation might be determined by the fact that the key social power entities, planning for the future of a town and most actively participating in its formation - private capital and self-government (rarely, the state) - have different understanding of urban public space significance to the town itself as well as its community, and also have different capabilities to change them. With commercial logic of benefit, typical under conditions of capital prevalence, an, undeveloped space in a town center can be hardly explainable in commercial terms, especially where land is expensive; and only in rare cases the commercial logic can appreciate real value added and social attraction created by the urban public space. On the one hand, in conditions of urban development under rapid and wild capitalism the self-government lacks leverage and power to implement its duties, form and/or take care of public spaces in a town. On the other hand, it should be taken into consideration that tradition of self-government and public space has been terminated and exterminated in Lithuania for half a century. 


\section{Changing Concept of Urban Public Space}

Today's sociocultural characteristics of public mentality (speaking in Peter Dinzelbacher's terms, Dinzelbacher, 1998) has certain inbuilt cultural unification of paradigms of sociality and privacy. (The problem discussed in several scientific branches and by a few authors.) It means that on the ideological level as well as in every-day experience the boundaries of privacy and sociality (publicity) are not always clearly set or defined. Speaking of a town and its public space system, a similar confusion of understanding could be witnessed, where objects and urban derivatives that so far have not been understood as traditional urban public space are usually referred to as such. These are certain buildings (such as cinemas theatres, libraries, etc.) or social-purpose buildings retained in social memories as focuses disseminating culture or focuses of social life, including centers and public spaces, Lietuva Cinema being an excellent example. Just going through the debates and discussions of a few recent years on public space and public interest, it is evident that the public space notion is used more often as it actually can be. Preliminary assumptions may be drawn that a certain conflict is inherent in a public space phenomenon itself, and that it may be representing by far more than at least physical function or purpose of a certain urban space in a town. Also such an approach fits perfectly well with the history and morphology of urban development, as the phenomena of urban public space and history of tradition reflect different social events happening or being manifested in urban public spaces. Although such a confusion in understanding of the concept itself as it currently exists may also show that certain layers in town formation and cultural tradition have not been absorb ed by society, and that may be preconditioned by the most recent revolution of social order (1990)... The last occupation in Lithuania is often seen as having caused the greatest damage not to the country's economy or political status, but rather to the mentality and continuity of most traditions of its people.

\section{New Typologies of Urban Public Spaces}

Traditional urban public space system is in continuous transformation in the sense of quality, structure as well as quantity. While a town is forming and expanding, it becomes more complex, multifunctional and multilayer ed. In the 19th century, through development of urbanization a number of urban public spaces were invented and formed, including indoor public spaces in public-purpose buildings (tradition going back to the Antiquity, but forgotten in certain later periods of urban development). Machine and technology development in construction provided for relatively cheap light roof covering of huge areas, what in turn ensured formation of new types of public spaces inside buildings. Thus a passage, atrium, roofed commercial and exhibition halls, etc. were born. Traditional outdoor urban public space system was enriched by new subtypes of public spaces, such as a boulevard (traditional streettype urban public space with morphological elements of a park - greenery), an embankment with or without green areas. Speaking of the public space of that time, one characteristic feature thereof should be emphasized: besides the separation of purpose, public spaces were became more civilized and refined. The same was happening to plazas that were gradually turned into squares. With the loss of function and purpose diversity, plaza was cultivated and refined in the course of time gaining some morphological features of a park, whereas its initial and traditional purpose and multifunction was reorganized ideologically and structurally in compliance with new urgent public needs and aesthetic doctrine, while the new derivatives of urban public spaces - markets - remained clearly monofunctional, in line with utilitarian and hygienic requirements. (e. g. a market on Lukiskes Square, Vilnius, at the end of the 19 th - the beginning of the 20th c). By becoming real public spaces in towns to belong to the whole population rather than the elite, parks were developed in compliance with similar space adornment and cultivation doctrine since the 17th $\mathrm{c}$ in Western Europe and 19th c in Lithuania.

Within the recent decade, the typological development of urban public spaces has also been changing. We face a phenomenon, where huge public-purpose buildings in Lithuanian towns (usually, commercial and recreational centers) start to replace urban public spaces. Such indoor centers embrace a lot of functions that are traditionally common to a town center or even urban public space (commercial lane, plaza, etc.) The Lithuanian context also has a peculiarity that public-purpose buildings of this type and size (commercial and, of course, recreational centers) occur in downtown areas or somewhere in their neighborhood. Their location and character often cause a certain contradiction to traditional town structure and traditional urban public space system, by duplicating or even sharking it. Besides, a phenomenon, when traditional public spaces occur in public-purpose buildings, develops a certain substitute or alternative for the real city life. Finally, such urban derivatives absorb the downtown functions, while a traditional city center with its own community culture and local style of living is gradually atrophying. In essence, such a virtuality stands in contradiction to traditional development of urban public spaces.

Thus, in some cases the recent and rapid wave of urbanization causes temporal (hopefully) atrophy of some traditional public spaces in towns (Laisvès Avenue in Kaunas). But by no means we can state that urban public space is perishing. Rather, it is not developed and formed as intensively as the whole city is developed and formed. Attention to the downtown and its infrastructure development does not comply with the development of the public space system in such a town, although traditionally the two cannot or, rather should not, exist separately. For example, the public space of Vilnius embankment now looks more like a wilderness rather than a solid city embankment, and we can find more of such examples. The social power entity (self-government), the decision-making body for formation of such spaces, is still too weak, and the social power entity (private capital or financial elite) so far understands only the commercial benefit of sociality and locates public spaces inside buildings.

In the mid 20th century, through formation of its own Lenin Square in each major town all over the country, a representative state public-space type was formed and developed in Lithuania. In the same period, the plaza type of the public space lost its significance and purpose through its gradual transformation into a park-like space. It is interesting though that during the Soviet period such park-type public spaces were formed in the places of former cemeteries, without even moving them out, but just by demolishing the tombs.

\section{Society's Changed Requirements to Public Spaces}

In recent 18 years of independence, there were a number of attempts - usually in the form of architectural competitions - to solve the reconstruction problems of former ideological urban public spaces. This year the need has become even more urgent. 
And it even has gained some features of a recurrent phenomenon with discussions on the quality of former administration sanctuaries and public spaces representing the state power, even if this happens again on the ideological level. The third wave of urbanization still continuing in Lithuania has been influencing the process of public space formation quite slowly and non-intensively. Today it is hard to find any examples of essential reformation of public spaces. There are no results or signs that could clearly indicate the ongoing process of public space formation with any clearly expressed quality indicators. The current situation has obvious features of stagnation. The key aspect of public space formation of the recent decade has been deconstruction, or the process through which many formerly important urban public spaces have lost their essential element - MONUMENT to Lenin. Lenin monuments have been removed from all the representative squares that used to identify the soviet ideology. Unfortunately, nothing new has been suggested in their place.

Another noteworthy public space formation feature is creation of monuments within existing spaces (see the Figure: former Černiachovskis Square and current Municipality Square in Vilnius.) In this case, the monument is erected without changing the compositional principle of a public space and without finding any appropriate solution to the relationship between such a monument and its surrounding environment - public space.

\section{Contemporary Trends and Ideas of Urban Public Space Formation}

After considering urban public space design solutions and related public discussions of recent years, the following key trends may be distinguished:

a) Implemented examples of public space design solutions are limited by topicality of a solution, where the space quality remains unchanged, with the focus on its finish and changes, without essential transformation of the space formation principle.

b) When new monuments are being formed in place (or almost in place) of the old ones, essential changes are made to the dominant's rather than space's quality.

c) In the quality aspect, the newest design proposals for urban space formation are usually of a high artistic value, reflecting fundamental traditions of Western European urban public spaces, especially those of multifunction and democracy. The society, however, partly determining the fate of future spaces and orientated more towards solutions at the other end of the ideological spectrum, frequently can change just the facade, the external side of a public space in the most primitive way. It signals that the historical memory and social mentality have not been fully changed and are orientated towards the past rather than future. Since the urban development tradition in Lithuania has changed radically at least three times within the recent fifty years, there is no such a generation who would be able to protect the tradition and seek for its continuity. Looking through the examples of the new est projects and ideas suggested for transformation of former representative Lenin squares, one clearly positive feature could be seen. New ideas and proposals are appearing able to evaluate the recent past in a conceptualized and impartial way, offering universal and also suggestive public space images, avoiding empty decorativeness, pomp and preachment.

Towns reflect the societies that created them. They also represent public values and mentality archetypes. The processes of urban space formation and use only confirm the aforementioned link. Tradition of urban public space formation is as old as Antiquity. Consistently such a formation is inseparable from the sociocultural context and its characteristics (according to Lewis Mumford). Today however, the manner and principles of urban public space formation show contemporary social and cultural values dominant in Lithuania. The fact that only now, after 18 years of independence, the country attempts to reconsider the formation of key public spaces in its towns shows the society's immaturity for making solutions. The transformation of the Lithuanian urban public spaces has just begun. So far, it has provoked only social confrontation rather than fruitful discussion. It is also likely that, in the context of current difficult economic situation, the transformation processes of urbanization and public space formation will get slower. So, we will have to wait for results.Keywords: urban morphology, public space, square, semiological text, trends.

Keywords: urban morphology, public space, square, semiological text, trends.

\section{TOMAS GRUNSKIS}

PhD, Assoc Prof., Dept of Architectural Theory and Fundamentals, Vilnius Gediminas Technical University,

Pylimo g. 26/Traku g. 1, LT-01132 Vilnius, Lithuania.

E-mail: grunskis@gmail.com

Publications: of author of 58 articles in popular professional and scientific magazines Research interests: urban morphology and anthropology, urban design and public space formation, interdisciplinary research. Projects: author and co-author of several winning projects in urban design and architecture. 